\title{
Solitary juxtacortical lesion associated with anti-N-methyl-D-aspartate receptor encephalitis: a case report
}

\author{
Rupan Gao', Xiang Zhang ${ }^{2}$, Abhijeet Kumar Bhekharee ${ }^{3}$ and Yue Zhang ${ }^{2^{*}}$ (D)
}

\begin{abstract}
Background: Anti-N-methyl-D-aspartate (NMDA) receptor encephalitis is a severe autoimmune encephalitis mediated by anti-NMDA receptor antibodies. Brain MRI manifestations vary and are non-specific. If there are any lesions, they tend to be diffusely or multifocally distributed. Solitary lesion is relatively rare.

Case presentation: We report a 16-year-old girl who initially presented with focal seizures but developed severe psychiatric and extrapyramidal symptoms later on. Brain MRI revealed a solitary juxtacortical demyelinating lesion in the left frontal lobe. No enhancement was noted. Electroencephalogram captured epileptiform discharges in the same region. NMDAR IgGs were tested positive in the serum and cerebrospinal fluid. Corticosteroid and intravenous IgG were administered and the patient completely recovered. Brain MRI revealed a fainter lesion in the left frontal lobe.

Conclusion: In very rare instances, anti-NMDA receptor encephalitis can present with a solitary brain lesion. A full panel of antibodies for autoimmune encephalitis is the key leading to the diagnosis.
\end{abstract}

Keywords: Seizure, Juxtacortical lesion, Demyelination, Electroencephalogram, Anti-N-methyl-D-aspartate receptor encephalitis

\section{Background}

Anti-N-methyl-D-aspartate (NMDA) receptor encephalitis was first described by Dalmau, et al., in 2007 [1]. Clinical picture covers a wide range of symptoms, including behavioral and psychiatric problems, memory loss, seizures, central hypoventilation, and movement disorders [1]. Brain MRI manifestations vary and are non-specific. More than half of the patients have normal MRI images [2]. If there are any brain lesions, they are more likely to be multifocal or diffuse $[2,3]$. The most common finding on electroencephalogram (EEG) is diffuse slowing [4]. We herein report a case of anti-NMDA receptor

\footnotetext{
*Correspondence: zygadene@163.com

${ }^{2}$ Department of Neurology, Huashan Hospital, Fudan University, No. 12 Mid Urumqi Road, Jin'an District, Shanghai 200040, China

Full list of author information is available at the end of the article
}

encephalitis initially presenting with focal seizures and. a left frontal juxtacortical lesion after brain MRI.

\section{Case presentation}

A 16-year-old girl presented to the emergency room with status epilepticus which was preceded by 10 -daylong period of recurrent seizures. Ten days ago, she began to suffer from recurrent jerky movements in the right arm which sometimes evolved to generalized clonic-tonic seizures. Frequency and duration gradually increased despite the use of levetiracetam $500 \mathrm{mg}$ Q12. Eventually, after the development of status epilepticus, she was sent to the emergency room where intravenous diazepam was injected. When she was transferred to the ward, she was sedated. Brain MRI revealed a left frontal unenhanced juxtacortical demyelinating lesion (Fig. 1 a, left and middle). EEG showed left frontal continuous

(C) The Author(s). 2020 Open Access This article is licensed under a Creative Commons Attribution 4.0 International License, which permits use, sharing, adaptation, distribution and reproduction in any medium or format, as long as you give appropriate credit to the original author(s) and the source, provide a link to the Creative Commons licence, and indicate if changes were made. The images or other third party material in this article are included in the article's Creative Commons licence, unless indicated otherwise in a credit line to the material. If material is not included in the article's Creative Commons licence and your intended use is not permitted by statutory regulation or exceeds the permitted use, you will need to obtain permission directly from the copyright holder. To view a copy of this licence, visit http://creativecommons.org/licenses/by/4.0/ The Creative Commons Public Domain Dedication waiver (http://creativecommons.org/publicdomain/zero/1.0/) applies to the data made available in this article, unless otherwise stated in a credit line to the data. 

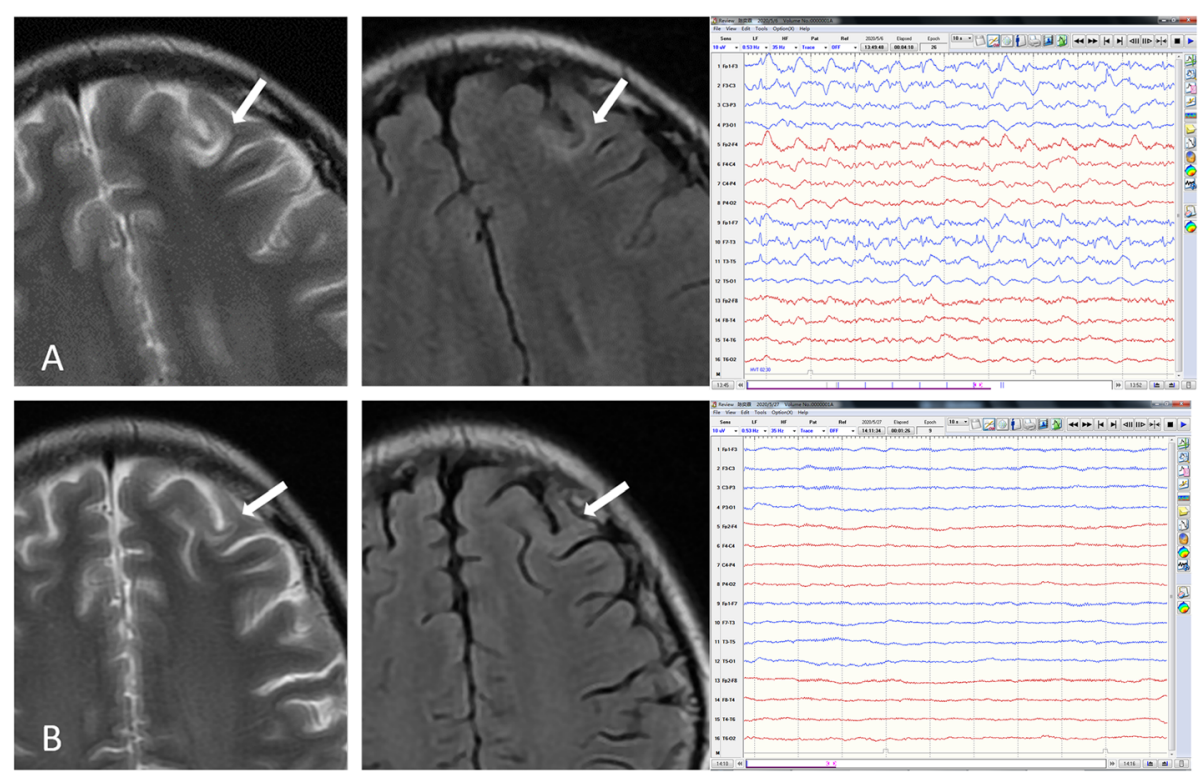

Fig. 1 Brain MRI and EEG before and after treatment. Before treatment, T2WI and FLAIR (a, left and middle) showed a left frontal juxtacortical high signal intensity (upper arrows). EEG (a, right) revealed continuous $1.5 \mathrm{~Hz}$ spike wave complexes over the left frontal lobe. One month after admission, the lesion became faint on T2WI (b, left, arrow) and nearly undiscernible on FLAIR (B, middle, arrow). EEG (b, right) showed normal electrical activity

epileptiform activities (Fig. 1a, right). Intravenous diazepam was tapered off and oral levetiracetam $1000 \mathrm{mg}$ Q12 were prescribed. We also considered lesion resection if the seizures could not be controlled. On day 3, seizures stopped, but the patient was found to be irritable, aggressive and labile. Levetiracetam was replaced by oxcarbazepine $600 \mathrm{mg}$ Q12 and Depakin $500 \mathrm{mg}$ Q12 to reduce side effects. Nevertheless, her mental status continued to worsen. On day 7 she developed delirium, hallucination, delusion, insomnia, oromandibular dystonia, and bradykinesia.

On physical examination, she was agitated, mute and uncooperative. Neurological examination highlighted bradykinesia, nystagmus on lateral gaze, jaw-opening dystonia, difficulty in sticking out tongue, cogwheel rigidity in limbs and shuffling gait. Cerebrospinal fluid (CSF) analysis after lumbar puncture showed normal protein and glucose level but leukocytes were elevated to $17 \times 10^{\wedge} 6 / \mathrm{L}$. Next generation sequencing for pathogen in CSF was unremarkable. NMDAR-antibody was positive in both serum and CSF samples (diluted 1:100) by cell-based assay (CBA). LGI1, CASPR2, AMPA1, AMPA2, GABAB, DPPX, IgLON5, AQP4, MOG and GFAP were all negative. CSF oligoclonal band was absent. Ovary teratoma was not detected by B-mode ultrasound. A repeat EEG showed diffuse beta waves without previous left frontal epileptiform activities. Anti-NMDA receptor encephalitis was considered. She was started on intravenous methylprednisone of $500 \mathrm{mg}$ daily for 5 days and tapered. Two rounds of IV immunoglobulin $(0.4 \mathrm{~g} /$ $\mathrm{kg} / \mathrm{d} \times 5$ days) were used. Her mental status gradually stabilized. Furthermore, dystonia and bradykinesia decreased. On day 30, brain MRI revealed a faint left frontal juxtacortical lesion (Fig. 1b, left and middle). No other abnormalities were observed. EEG showed no epileptiform activities (Fig. 1b, right). On day 43, she was discharged with moderate dystonia. Thirty days after discharge, all the symptoms had resolved. She had no memory of the disease. The demyelinating lesion was even fainter on MRI and EEG showed normal result.

\section{Discussion and conclusion}

Anti-NMDA receptor encephalitis is an autoimmune encephalitis with a wide range of symptoms. Common early symptoms include behavioral and speech problems, seizures, and abnormal movements [5]. While generalized seizures are common in female patients [6], focal seizures are more prevalent in male [6] and pediatric patients [7]. More than half of the patients have normal MR results $[2,8]$. In those with brain lesions, hippocampus is the most commonly affected site with frontal and temporal lobes in the second and third places respectively [2]. Patients who developed lesions, had status epilepticus lasting 6 days on average [9], however, since the seizure of our patient was controlled within $24 \mathrm{~h}$, her lesion could not be attributed to status epilepticus. What's more, MRI lesions subsequently resolve in most patients [9]. Anti-NMDA receptor encephalitis may occasionally overlap with demyelinating syndromes. The demyelinating lesions tend to be multifocal or diffuse [3]. EEG 
abnormalities in anti-NMDA receptor encephalitis include diffuse slowing, epileptiform discharges, extreme delta brush, polymorphic delta rhythm, focal slowing and diffuse beta activities [4]. Diffuse slowing is the most common finding. Lateralized periodic discharges are uncommon [4].

The presence of right-sided focal seizures, solitary left frontal lesion and localized epileptiform discharges in our case highly suggested a focal process, such as focal cortical dysplasia or glioma. In this context, unnecessary surgical procedure is very likely to be performed. Rosenbloom $\mathrm{MH}$, et al. reported a similar case of refractory seizures together with a focal enhancing lesion found on brain MRI, whereafter, the left middle frontal gyrus was surgically resected. Surgery did not bring any benefit [10]. Due to the fact that in the patient presented here seizures were controlled at early stage and psychiatric problems and movement disorders were exhibited later on, the patient did not undergo surgical procedure. Testing for anti-NMDAR antibodies in CSF and blood is the key to the correct diagnosis of anti-NMDAR encephalitis, but the false positiveness should be noted. Lu J, et al. reported a case of solitary cortical astrocytoma misdiagnosed as anti-NMDAR encephalitis due to positive NMDAR antibodies in serum and CSF. The only symptom was partial seizures in the right limb [11]. False positiveness of anti-NMDAR antibody in both serum and CSF was also reported in Lyme disease [12], False positiveness in serum has been found in multiple sclerosis [13], Creutzfeldt-Jakob disease [14], and schizophrenia [15].Therefore, besides autoantibodies detection, careful clinical observation is also warranted. False negative result is also possible. In a study by McCracken L et al., 65 serum and 32 CSF samples among 731 samples were indeterminate for antibodies with CBA. Reevaluation with immunohistochemistry for reactivity to brain sections could further improve diagnostic accuracy [16]. As patients recover, their antibody titres in serum and CSF may decrease during monitoring, however, many patients remain antibody-positive even after recovery [17].

In conclusion, we have described an atypical case of anti-NMDA receptor encephalitis. Radiological and neuroelectrophysiological examinations impeded rather than facilitating the correct diagnosis. Testing CSF/blood for disease-associated autoantibodies is appropriate in patients (especially young people) with focal seizures, progressive psychiatric symptoms, emergent movement disorders and CSF pleocytosis.

\section{Abbreviations}

NMDA: Anti-N-methyl-D-aspartate; MRI: Magnetic resonance imaging;

EEG: Electroencephalogram; CSF: Cerebrospinal fluid; CBA: Cell-based assay; LGI1: Leucine-rich glioma inactivated 1; CASPR2: Contactin-associated protein-like 2; AMPA: a-amino-3-hydroxy-5-methyl-4-isoazolepropionic acid;
GABAB: $y$-Aminobutyric acid B; DPPX: Dipeptidyl-peptidase-like protein-6; AQP4: Aquaporin-4; MOG: Myelin oligodendrocyte glycoprotein; GFAP: Glial fibrillary acidic protein

\section{Acknowledgements}

Not applicable.

\section{Authors' contributions}

R.P.G.: patient management, initial manuscript preparation; X.Z.: initial manuscript preparation; B.A.K.: critical review; Y.Z.: MRI and EEG analysis, critical review; final approval of the manuscript to be submitted. All authors have read and approved the manuscript of "Solitary juxtacortical lesion associated with anti-N-methyl-D-aspartate receptor encephalitis: a case report".

\section{Funding}

None.

Availability of data and materials

Not applicable.

Ethics approval and consent to participate

The study is approved by ethics committee of Huashan hospital.

\section{Consent for publication}

Written informed consent was obtained from the patient's parent for publication of this case report and any accompanying images. A copy of the written consent is available for review by the Editor of this journal.

\section{Competing interests}

The authors declare that they have no competing interests.

\section{Author details}

${ }^{1}$ Department of Hematology, Zhongshan Hospital, Fudan University, Shanghai, China. ${ }^{2}$ Department of Neurology, Huashan Hospital, Fudan University, No. 12 Mid Urumqi Road, Jin'an District, Shanghai 200040, China. ${ }^{3}$ Shanghai Medical College, Fudan University, Shanghai, China.

Received: 20 August 2020 Accepted: 9 November 2020

Published online: 20 November 2020

\section{References}

1. Dalmau J, Tuzun E, Wu HY, et al. Paraneoplastic anti-N-methyl-D-aspartate receptor encephalitis associated with ovarian teratoma. Ann Neurol. 2007; 61(1):25-36

2. Zhang $T$, Duan $Y, Y e J$, et al. Brain MRI characteristics of patients with anti$\mathrm{N}$-methyl-D-aspartate receptor encephalitis and their associations with 2year clinical outcome. AJNR Am J Neuroradiol. 2018:39(5):824-9.

3. Titulaer MJ, Hoftberger R, lizuka T, et al. Overlapping demyelinating syndromes and anti-N-methyl-D-aspartate receptor encephalitis. Ann Neurol. 2014;75(3):411-28.

4. Gillinder L, Warren N, Hartel G, Dionisio S, O'Gorman C. EEG findings in NMDA encephalitis - a systematic review. Seizure. 2019;65:20-4.

5. Florance NR, Davis RL, Lam C, et al. Anti-N-methyl-D-aspartate receptor (NMDAR) encephalitis in children and adolescents. Ann Neurol. 2009; 66(1):11-8.

6. Viaccoz A, Desestret V, Ducray F, et al. Clinical specificities of adult male patients with NMDA receptor antibodies encephalitis. Neurology. 2014;82(7): 556-63

7. Sands TT, Nash K, Tong S, Sullivan J. Focal seizures in children with antiNMDA receptor antibody encephalitis. Epilepsy Res. 2015;112:31-6.

8. Titulaer MJ, McCracken L, Gabilondo I, et al. Treatment and prognostic factors for long-term outcome in patients with anti-NMDA receptor encephalitis: an observational cohort study. Lancet Neurol. 2013;12(2): 157-65.

9. Giovannini G, Kuchukhidze G, McCoy MR, Meletti S, Trinka E. Neuroimaging alterations related to status epilepticus in an adult population: definition of MRI findings and clinical-EEG correlation. Epilepsia. 2018;59(Suppl 2):120-7.

10. Rosenbloom MH, Samuelsson MK, Brogan ME, Tran-Lim TA. NMDA receptor antibody encephalitis presenting with enhancing lesion and seizures. Neurol Clin Pract. 2017;7(5):433-5. 
11. Lu J, Zhang JH, Miao AL, et al. Brain astrocytoma misdiagnosed as antiNMDAR encephalitis: a case report. BMC Neurol. 2019;19(1):210.

12. Knudtzen FC, Nilsson AC, Skarphedinsson S, Blaabjerg M. False-positive antiNMDA receptor antibodies in severe case of Lyme neuroborreliosis. Neurol Sci. 2020:41(1):197-9.

13. Ramberger M, Bsteh $\mathrm{G}$, Schanda $\mathrm{K}$, et al. NMDA receptor antibodies: a rare association in inflammatory demyelinating diseases. Neurol Neuroimmunol Neuroinflamm. 2015;2(5):e141.

14. Mackay G, Ahmad K, Stone J, et al. NMDA receptor autoantibodies in sporadic Creutzfeldt-Jakob disease. J Neurol. 2012;259(9):1979-81.

15. Chiu NC, Lin YJ, Tzang RF, et al. Optimization of an anti-NMDA receptor autoantibody diagnostic bioassay. Front Neurol. 2018;9:661.

16. McCracken L, Zhang J, Greene M, et al. Improving the antibody-based evaluation of autoimmune encephalitis. Neurol Neuroimmunol Neuroinflamm. 2017:4(6):e404.

17. Gresa-Arribas N, Titulaer MJ, Torrents A, et al. Antibody titres at diagnosis and during follow-up of anti-NMDA receptor encephalitis: a retrospective study. Lancet Neurol. 2014;13(2):167-77.

\section{Publisher's Note}

Springer Nature remains neutral with regard to jurisdictional claims in published maps and institutional affiliations.

Ready to submit your research? Choose BMC and benefit from:

- fast, convenient online submission

- thorough peer review by experienced researchers in your field

- rapid publication on acceptance

- support for research data, including large and complex data types

- gold Open Access which fosters wider collaboration and increased citations

- maximum visibility for your research: over $100 \mathrm{M}$ website views per year

At BMC, research is always in progress.

Learn more biomedcentral.com/submissions 